\title{
Preparasi dan Karakterisasi Dye-sensitized Solar Cell (DSSC) dengan Pewarna Ekstrak Jeruk: Pengaruh Variasi Komposisi Karotenoid dan Flavonoid Terhadap Efisiensi Sel Surya
}

\author{
Ernawita, ${ }^{1, *}$ Irwansyah, ${ }^{2}$ Dyah Sawitri, ${ }^{2}$ dan Ruri Agung Wahyuono ${ }^{2, \dagger}$ \\ ${ }^{I}$ Program Studi Agroteknologi, Universitas Al-Muslim Aceh, \\ Jln. Almuslim, Matangglumpangdua, Bireuen, Aceh, 24261 \\ ${ }^{2}$ Departemen Teknik Fisika, Institut Teknologi Sepuluh Nopember, Kampus ITS Sukolilo, Surabaya, 60111
}

\begin{abstract}
Intisari
Sel surya berpewarna tersensitisasi atau dikenal dengan dye-sensitized solar cell (DSSC) dengan menggunakan semikonduktor $\mathrm{ZnO}$ dan ekstrak jeruk sebagai molekul pewarna sensitisasi (dye) telah difabrikasi dan dikarakterisasi. Ekstrak jeruk yang digunakan adalah jeruk purut biasa dan jeruk nipis. Hasil estimasi berdasarkan spektrum infra merah yang ditunjang dengan studi pendahulu menggunakan HPLC dan LC-MS menunjukkan bahwa ekstrak jeruk purut biasa dan jeruk nipi mengandung karotenoid jenis lutein. Ekstrak jeruk purut biasa kaya akan kandungan flavonoid seperti naringin, hesperidin dan tangeretin, sedangkan ekstrak jeruk nipis kaya akan kandungan quercetin, sakuranetin, dan tangeretin. Kombinasi kandungan flavonoid berpengaruh pada sifat optik dan elektronik dari ekstrak. Hasil fabrikasi dan karakterisasi arus-tegangan DSSC menggunakan elektroda aktif $\mathrm{ZnO}$ dan pewarna ekstrak jeruk menunjukkan hasil bahwa tegangan rangkaian terbuka $\left(\mathrm{V}_{\circ c}\right)$ dan faktor pengisian (fill factor, $\mathrm{FF}$ ) relatif sama untuk semua jenis ekstrak jeruk yaitu $\mathrm{V}_{\text {oc }} \approx 0,340 \mathrm{~V}$ dan $\mathrm{FF} \approx 0,4$. Rapat arus pada rangkaian singkat terbesar $\left(\mathrm{J}_{s c}=0,956 \mathrm{~mA} . \mathrm{cm}^{-2}\right)$ dihasilkan DSSC dengan molekul pewarna ekstrak jeruk purut biasa dan efisiensi yang mampu dicapai sebesar $0,122 \%$.
\end{abstract}

\begin{abstract}
Dye-sensitized solar cells (DSSC) employing $\mathrm{ZnO}$ and citrus extracts as sensitizer were fabricated and characterized. Citrus extracts used in this study were isolated from Citrus hysterics and Citrus Auran-Tii folia (kafir lime). Infrared spectroscopy study, corroborated with HPLC and LC-MS, estimates that both citrus extracts contain a high content of lutein as carotenoids. In addition, Citrus hysteric extracts contain rich flavonoid including naringin, hesperidin, and tangeritin, while kafir lime extracts are characterized by high content of quercetin, sakuranetin, and tangeritin. The combination of different flavonoids and carotenoids in both extracts results in different optical and electronic properties. The current-voltage measurement of ZnO-based DSSC shows that the open circuit voltage $\left(\mathrm{V}_{\circ c}\right)$ and fill factor $(\mathrm{FF})$ are unaffected upon using different dyes, i.e. $\mathrm{V}_{\circ c} \approx 0.340 \mathrm{~V}$ and $\mathrm{FF} \approx 0.4$. The highest short circuit current $\left(\mathrm{J}_{s c}=0.956 \mathrm{~mA} . \mathrm{cm}^{-2}\right)$ is generated in DSSC utilizing Citrus hysteric extracts and yield efficiency up to $0.122 \%$.
\end{abstract}

KaTA KUnCI: Dye-sensitized solar cell, $\mathrm{ZnO}$, Carotenoid, Flavonoid, Citrus extract, Efficiency http://dx.doi.org/10.12962/j24604682.v13i3.2839

\section{PENDAHULUAN}

Teknologi konversi energi surya generasi ketiga yang murah dan andal menjadi salah satu topik hangat dalam perkembangan sel surya lapisan tipis. Salah satu bentuk sel surya lapisan tipis adalah sel surya berpewarna tersensitisasi (SSPT) atau lebih jamak disebut dye-sensitized solar cell [1,2]. DSSC terdiri dari fotoanoda yang terbuat dari semikonduktor tipe-n (umumnya $\mathrm{TiO}_{2}$ dan $\mathrm{ZnO}$ ), molekul pewarna (S), elektrolit $\left(\mathrm{I}_{3}^{-} / \mathrm{I}^{-}\right)$dan elektroda pembanding $(\mathrm{Pt})$. Berbeda dengan sel

\footnotetext{
*E-MAIL: ernawita.ernawita@gmail.com
}

†E-MAIL: ruri.tf014@gmail.com surya berbasis $\mathrm{Si}$, pemisahan muatan pada DSSC terjadi pada banyak antarmuka. Arus listrik pada DSSC dihasilkan dari injeksi elektron $\left(\mathrm{S} *\left|\mathrm{TiO}_{2} \rightarrow \mathrm{S}^{-}\right| \mathrm{TiO}_{2}+\mathrm{e}_{C B\left(T i O_{2}\right)}\right)$ setelah fotoeksitasi elektron molekul pewarna oleh radiasi cahaya ( $\mathrm{S}$ $\left.+\mathrm{hv} \rightarrow \mathrm{S}^{*}\right)$. Molekul pewarna yang tereduksi karena kehilangan elektron kemudian diregenerasi dengan penangkapan elektron oleh senyawa penerima dalam elektrolit $\left(3 \mathrm{~S}^{-} \mid \mathrm{TiO}_{2}+\right.$ $\left.\mathrm{I}_{3}^{-} \rightarrow \mathrm{S} \mid \mathrm{TiO}_{2}+3 \mathrm{I}^{-}\right)$. Namun demikian, terdapat mekanisme rekombinasi (intersepsi elektron) yang memungkin terjadi antara elektron pada pita konduksi dengan senyawa $\mathrm{I}_{3}^{-}$dalam elektrolit sehingga mengurangi nilai arus foto yang dihasilkan DSSC [1]. Dalam perkembangan DSSC, terdapat ruang improvisasi untuk memperoleh efisiensi yang lebih tinggi diantaranya perekayasaan semikonduktor, struktur molekul pewarna, pasangan reduksi-oksidasi elektrolit, dan material 
elektroda pembanding [2-5].

Pada perekayasaan semikonduktor untuk anoda DSSC, penggunaan material $\mathrm{ZnO}$ cukup menjanjikan dikarenakan sifat fisika yang lebih baik dibandingkan $\mathrm{TiO}_{2}$. Potensial pita konduksi lebih tinggi dibandingkan $\mathrm{TiO}_{2}$ sehingga dapat menghasilkan tegangan yang lebih besar, mobilitas elektron yang sangat cepat sehingga berpotensi mengurangi faktor rekombinasi, serta memiliki struktur dan morfologi yang dapat diubah-ubah menyesuaikan kondisi sintesis [6-8]. Selain itu pemanfaatan bahan pewarna organik juga mulai dikembangkan cukup masif dikarenakan molekul pewarna kompleks Pewarna kompleks berbasis Ruthenium dikategorikan sebagai bahan anorganik yang tidak ramah lingkungan serta membutuhkan biaya sintesis yang mahal. Oleh karena itu, penelitian tentang bahan pewarna organik baik sintetik ataupun ekstraksi bahan alam menjadi alternatif untuk menguji unjuk kerja DSSC [9-12]. Gugus hidroksil $(\mathrm{OH})$ atau karboksil $(-\mathrm{COOH})$ pada senyawa organik, seperti antosianin dan karotenoid serta derivatifnya, dapat berikatan kovalen dengan $\mathrm{Zn}^{2+}$ atau $\mathrm{Ti}^{4+}$ sehingga sangat prospektif sebagai molekul sensitisasi pada DSSC. Berbagai ektrak buah dan daun seperti kulit manggis, daun nanas kerang, klorofil dan bunga sepatu yang dikenal mengandung antosianin yang tinggi dan berhasil menunjukkan karakteristik sel surya [9, 10, 13]. Selain bahan alam tersebut, jeruk berikut dengan produk sampingnya seperti kulit jeruk dikenal sebagai sumber bio yang kaya akan karotenoid dan flavonoid [14, 15]. Namun demikian, eksplorasi ektrak kulit jeruk sebagai bahan pewarna untuk DSSC sangat jarang dilaporkan sebelumnya. Oleh karena itu, pada makalah ini disajikan fabrikasi dan karakterisasi secara komprehensif terkait variasi komposisi ekstrak jeruk (jeruk purut biasa dan jeruk nipis) terhadap unjuk kerja (efisiensi) DSSC. Adapun karakterisasi sifat optik dan komposisi ekstrak jeruk dikarakterisasi dengan mengukur spektrum serapan (absorbansi) infra merah, absorbansi dan emisi UV/Vis. Sifat elektrokimia ekstrak jeruk dianalisis dari hasil pengukuran cyclic voltammogram serta efisiensi DSSC diukur dengan menganalisis kurva arus-tegangan dan daya-tegangan dengan iluminasi simulator surya $\left(100 \mathrm{mWcm}^{-2}\right)$.

\section{METODE PENELITIAN}

\section{Ekstraksi karotenoid dan flavonoid dari kulit jeruk}

Ekstrak jeruk yang digunakan dalam studi ini adalah ekstrak kulit jeruk purut biasa, dan jeruk nipis. Detil karakteristik jeruk dapat dilihat pada referensi [14, 15]. Karotenoid dari jeruk diekstrak menggunakan metode yang sama pada penelitian sebelumnya. Sejumlah $500 \mathrm{mg}$ dari kulit jeruk diekstrak dengan pelarut metanol:tetrahydrofuran $(1: 1, \mathrm{v} / \mathrm{v})$ menggunakan ultra turrax hingga larutan ekstraksi berubah tidak bewarna. Ekstraksi polifenol dilakukan sebagai berikut: sampel kulit jeruk dihidrolisis menggunakan $\mathrm{HCl}$ dan $\mathrm{NaOH}$ untuk melepaskan senyawa polifenol dari matrik sampel. Sampel yang telah dihidrolisis diekstrak menggunakan pelarut etanol:air (1:a, v/v).

\section{Sintesis partikel nano $\mathrm{ZnO}$}

Sintesis partikel nano $\mathrm{ZnO}$ dilakukan melalui dua tahap reaksi sehingga diperoleh aggregat bola [3, 16, 17]. Pada tahap pertama, 0,1M $\mathrm{Zn}\left(\mathrm{CH}_{3} \mathrm{COO}\right)_{2} \cdot 2 \mathrm{H}_{2} \mathrm{O}$ dilarutkan dalam 100 $\mathrm{ml}$ diethylene glycol (DEG) dan dipanaskan pada temperatur $180^{\circ} \mathrm{C}$ serta diaduk secara kontinyu selama 1 jam. Larutan kemudian berubah menjadi putih susu dan didinginkan untuk kemudian disentrifugasi sehingga terpisah antara presipitat dan pelarut sisa (supernatant). Pelarut sisa yang terdiri dari sisa-sisa DEG, $\mathrm{Zn}\left(\mathrm{CH}_{3} \mathrm{COO}\right)_{2} .2 \mathrm{H}_{2} \mathrm{O}$ yang tidak bereaksi, air dan produk-rpoduk reaksi lainnya disimpan untuk reaksi tahap kedua. Pada tahap kedua, $0,1 \mathrm{M} \mathrm{Zn}\left(\mathrm{CH}_{3} \mathrm{COO}\right)_{2} \cdot 2 \mathrm{H}_{2} \mathrm{O}$ dilarutkan dalam $100 \mathrm{ml}$ DEG dan dipanaskan tanpa diaduk. Ketika larutan reaksi mencapai temperatur $140^{\circ} \mathrm{C}, 10 \mathrm{ml}$ dari pelarut sisa ditambahkan sedikit demi sedikit hinga terjadi penurunan temperatur reaksi dan terjadi presipitasi $\mathrm{ZnO}$. Larutan kemudian dipanaskan lanjut hingga mencapai temperatur $160^{\circ} \mathrm{C}$ dan diaduk secara kontinyu selama 1 jam. Larutan kemudian didinginkan ke temperatur kamar dan disentrifugasi untuk memperoleh $\mathrm{ZnO}$ dengan aggregate bola yang terdispersi secara homogen.

\section{Karakterisasi semikonduktor dan dye}

Pola difraksi sinar $\mathrm{X}$ dari $\mathrm{ZnO}$ dilakukan menggunakan $\mathrm{X}$ ray diffractometer. Kandungan dalam ekstrak jeruk sebelumnya telah dikarakterisasi menggunakan HPLC dan LC-MS dan dilaporkan dalam artikel [14, 15]. Spektrometer serapan inframerah direkam menggunakan perangkat FTIR Nicolet iS10 (Thermo Scientific, Massachusetts, USA). Spektrum absorbansi pada rentang panjang gelombang 400-800 $\mathrm{nm}$ dari ektrak jeruk diukur dengan menggunakan spektrometer UV/vis sedangkan spektrum emisi diukur menggunakan fluorolog. Sifat elektrokimia diuji dengan mengukur karakteristik arus-tegangan pada cyclic voltammogram (CV) dengan elektroda kerja karbon dan elektroda pembanding kawat platina. Adapun elektroda referensi pada pengukuran $\mathrm{CV}$ adalah $\mathrm{Ag} / \mathrm{AgCl}$.

\section{Fabrikasi dan pengujian DSSC}

DSSC difabrikasi dengan struktur berlapis (sandwich) $[4,6]$. Pasta $\mathrm{ZnO}$ dengan pelarut ethanol dan DEG dideposisikan pada substrat FTO (F-doped tin oxide) dengan luas aktif $20 \mathrm{~mm}^{2}$ menggunakan metode doctor-blade serta kemudian dianil pada temperatur $450^{\circ} \mathrm{C}$ selama 1 jam untuk mendapatkan elektroda $\mathrm{ZnO}$. Pada tahapan sensitisasi, elektroda $\mathrm{ZnO}$ dipanaskan pada temperatur $80^{\circ} \mathrm{C}$ kemudian direndam dalam larutan ekstrak jeruk dengan pelarut etanol selama 24 jam. Elektroda $\mathrm{ZnO}$ yang telah direndam kemudian diangkat dan dibersihkan dengan etanol untuk menghilangkan ekstrak yang tidak terserab secara kimia. Selanjutnya elektroda $\mathrm{ZnO}$ disandwich dengan elektroda pembanding Pt. Elektroda pembanding disiapkan dengan melapiskan larutan $10 \mathrm{mM}$ hydrogen hexachloroplatinate (IV) hydrate $\left(\mathrm{H}_{2} \mathrm{PtCl}_{6}, 99.9 \%\right)$ dalam pelarut 2-propanol pada substrat kaca FTO (FTO, $\pm 10 \Omega$ ) dan dipanaskan pada temperatur $450^{\circ} \mathrm{C}$ selama 30 menit. Sebelum dilakukan pengujian arus-tegangan, elektrolit pasangan 


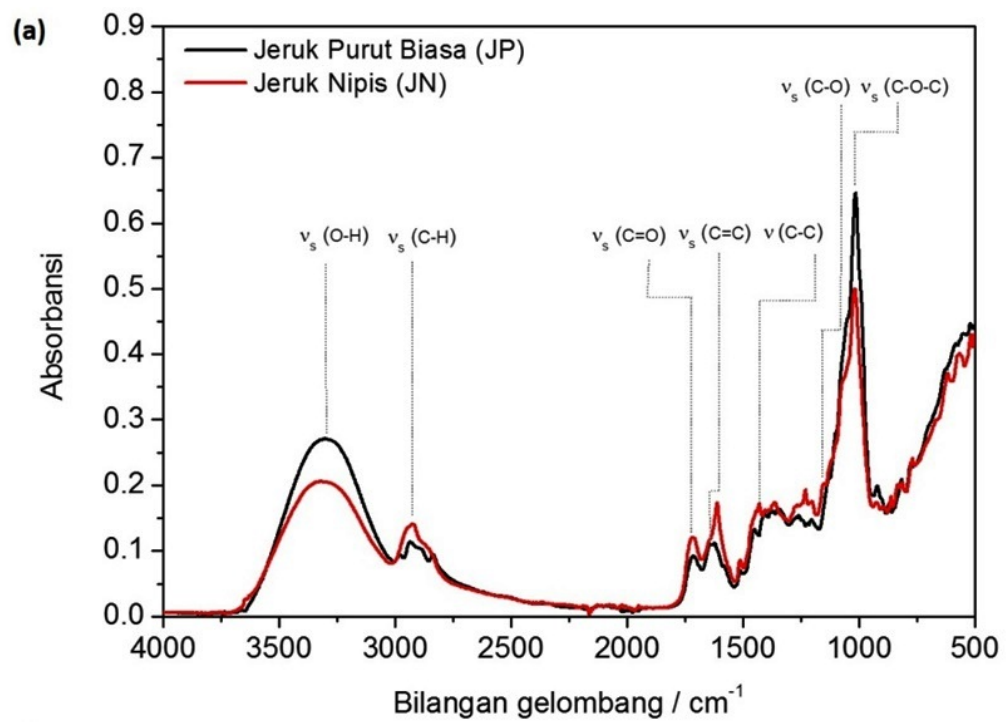

(b)


Gambar 1: (a) Spektrum absorbansi IR dari ekstrak jeruk purut biasa (JP) dan jeruk nipis (JN). (b) Struktur molekuler dasar dari karotenoid (kiri) dan flavonoid (kanan) yang dianalisis dari spektrum absorbansi IR.

redoks $\mathrm{I}_{3}^{-} / / \mathrm{I}^{-}$diinjeksikan ke dalam sel. Adapun elektrolit ini terdiri dari 0,5 $\mathrm{M}$ tert-butylammonium iodide, $0,1 \mathrm{M}$ Lithium iodide, 0,1 M iodine and 0,5 M 4-tert-butylpyridine yang dilarutkan dalam pelarut asetonitril. Pengujian arus-tegangan dilakukan menggunakan potensiostat Kethley dengan iradiasi solar simulator $100 \mathrm{~mW} . \mathrm{cm}^{-2}$ menggunakan filter AM1.5.

\section{HASIL DAN PEMBAHASAN}

Kandungan karotenoid dan flavonoid diestimasi menggunakan hasil pengukuran absorbansi IR yang menunjukkan karakter vibrasi harmonik dan vibrasi fundamental dari molekul tertentu. Berdasarkan studi berbasis absorbansi IR [18], analisis spektrum IR mengabaikan puncak-puncak pada rentang $>3500 \mathrm{~cm}^{-1}$ dikarenakan puncak absorpsi yang lebar dari vibrasi peregangan gugus hidroksil $(-\mathrm{OH})$ dapat bertumpang tindih dengan puncak absorpsi yang lain. Rentang absorbansi yang menjadi fokus analisis adalah 1000 hingga $3500 \mathrm{~cm}^{-1}$ dikarenakan pada rentang ini pita valensi dari gugus karbonil bersifat IR aktif.

Estimasi kuantitatif kandungan karotenoid dan flavonoid dilakukan dengan menggunakan program fitting berbasis particle swarm optimization (PSO) terhadap jumlahan dari dugaan kandungan karotenoid dan flavonoid yang ada di dalam ekstrak jeruk [19]. Proses optimasi menggunakan partikel swarm sejumlah 500 hingga 1000 dengan maksimum 1000 iterasi. Spektrum IR dari ekstrak jeruk purut manis dan jeruk nipis ditunjukkan pada Gambar 1. Pun- cak pada $3500-3200 \mathrm{~cm}^{-1}$ merupakan karakteristik vibrasi regangan $\mathrm{O}-\mathrm{H}$ dari makromolekul ataupun molekul air permukaan. Absorbansi pada rentang 3000-2800 $\mathrm{cm}^{-1}$ dapat disebabkan vibrasi peregangan $\mathrm{C}-\mathrm{H}$ dari gugus metil, metoksi dan metilena yang terdapat dari dua fraksi utama struktur molekuler flavonoid yaitu gugus benzopiron dan fenil. Vibrasi peregangan dari karbonil $(\mathrm{C}=\mathrm{O})$ dari gugus karboksil (COO) ditunjukkan dengan puncak spectrum pada rentang $1740-1710 \mathrm{~cm}^{-1}$. Puncak infra merah pada $1640 \mathrm{~cm}^{-1}$ merupakan penciri pergangan ikatan $\mathrm{C}=\mathrm{C}$ dari cincin benzena. Spektrum vibrasional pada rentang $1430-1455 \mathrm{~cm}^{-1}$ merupakan karakteristik senyawa alifatik dan aromatik (C-H) dari vibrasi deformasi planar gugus metil, metilena dan metoksi. Puncak absorbansi pada rentang $1300-1000 \mathrm{~cm}^{-1}$ menunjukkan vibrasi peregangan $\mathrm{C}-\mathrm{O}$ asam karboksilat dan alkanol, sedangkan absorbansi pada rentang $1130-1150 \mathrm{~cm}^{-1}$ berasosiasi dengan vibrasi $\mathrm{C}-\mathrm{O}-\mathrm{C}$ dan $\mathrm{O}-\mathrm{H}$ dari polisakarida. Karakteristik spektrum IR pada bilangan gelombang dibawah $900 \mathrm{~cm}^{-1}$ merupakan karakteristik sidik jari (finger print zone). Secara umum hasil fitting terhadap spektrum IR menunjukkan bahwa ekstrak jeruk purut biasa dan jeruk nipis mengandung beberapa jenis karetonid (lutein dan zeaxanthin) serta berbagai derivatif flavonoid seperti flavonol, flavanon, flavon O-glycosides dan flavon polimetoksi (polymethoxylated flavones, PMFs). Kandungan karotenoid dan flavonoid pada ekstrak jeruk berdasarkan spektrum IR adalah sebagai berikut (data ditunjukkan hanya kandungan $>5 \%$ ): Ekstrak jeruk purut biasa mengandung naringin $(20 \%)$, hesperidin $(22 \%)$, neohesperidin (12\%), tangeretin (27\%) dan lutein 

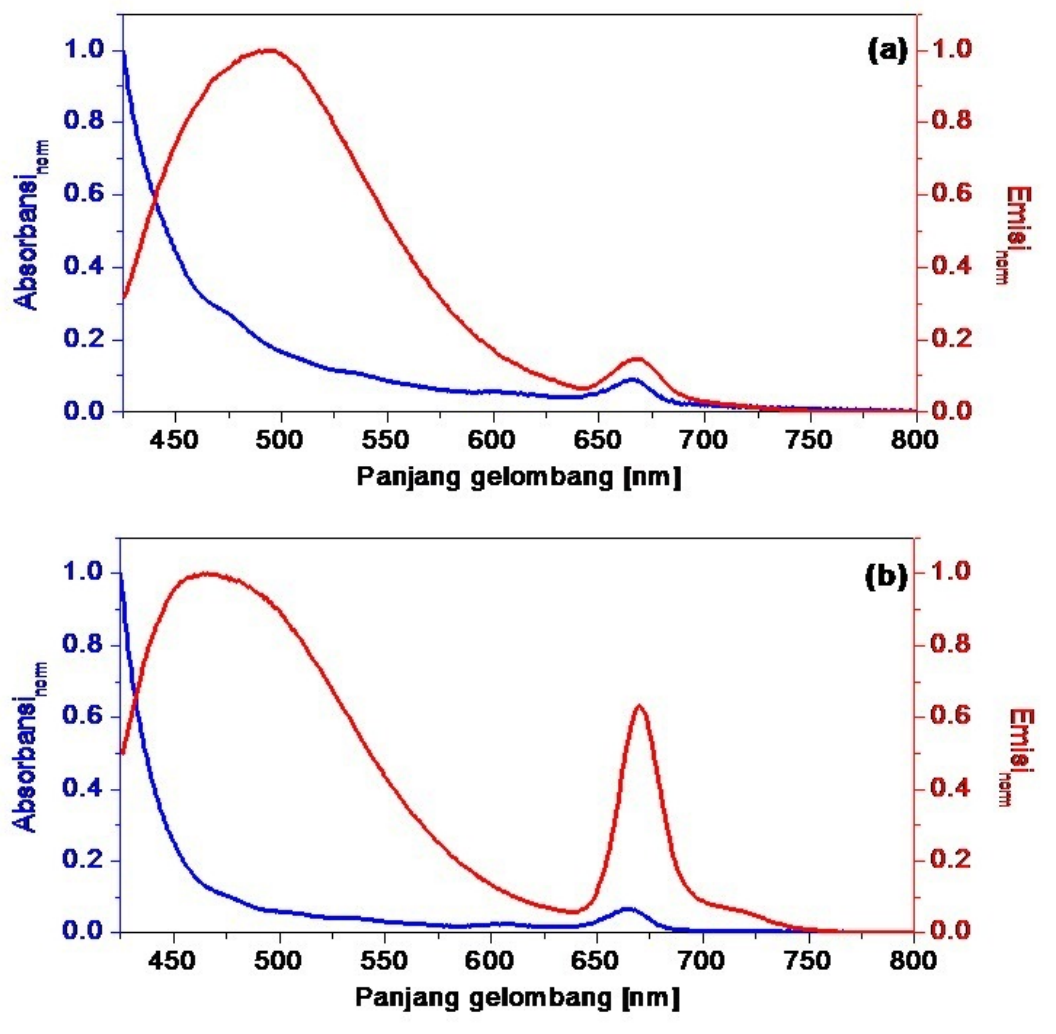

Gambar 2: Spektrum absorbansi pada panjang gelombang tampak dan NIR serta spectrum emisi untuk panjang gelombang eksitasi $410 \mathrm{~nm}$ dari ekstrak (a) jeruk purut dan (b) nipis.

(7\%), sedangkan ekstrak jeruk nipis mengandung quercetin (14\%), naringin $(12 \%)$, hesperidin (11\%), sakuranetin $(18 \%)$, nobiletin $(6 \%)$, tangeretin $(21 \%)$ dan lutein $(13 \%)$.

Pada Gambar 2 ditunjukkan karakteristik serapan dan emisi dari ekstrak kulit jeruk pada rentang panjang gelombang tampak dan near infrared (NIR). Ekstrak jeruk purut biasa memiliki karakteristik serapan pada panjang gelombang $475 \mathrm{~nm}$, $580 \mathrm{~nm}$, dan $668 \mathrm{~nm}$, sedangkan ekstrak jeruk nipis memiliki puncak serapan pada $470 \mathrm{~nm}, 605 \mathrm{~nm}$ (lemah), dan $670 \mathrm{~nm}$. Beberapa puncak absorbansi ekstrak jeruk ini dapat dikorelasikan dengan karakteristik absorbansi senyawa yang dominan dalam kandungan ekstrak, seperti: hesperidin memiliki absorbansi maksimum pada panjang gelombang 435, 525 dan $670 \mathrm{~nm}$; naringenin memiliki absorbansi maksimum pada panjang gelombang 410 dan $550 \mathrm{~nm}$; quercetin memiliki absorbansi maksimum pada panjang gelombang 510, 560 dan $690 \mathrm{~nm}[20,21]$. Turunan karotenoid yaitu lutein memiliki absorbansi maksimum pada 423, 445 dan $474 \mathrm{~nm}$. Selain itu absorbtivitas molar dari spektrum absorbansi menunjukkan bahwa ekstrak jeruk purut biasa lebih berpotensi untuk memanen iradiasi cahaya lebih besar dibandingkan ekstrak jeruk nipis. Evaluasi spektrum emisi dari masing-masing ekstrak jeruk menunjukkan bahwa kedua ekstrak memiliki karakteristik emisi yang hampir sama. Ekstrak jeruk memiliki emisi puncak pada $480 \mathrm{~nm}$ dan $680 \mathrm{~nm}$ dengan emisi pada $720 \mathrm{~nm}$ serta intensitas spektrum emisi pada panjang gelombang 475$525 \mathrm{~nm}$ lebih kuat dibandingkan intensitas emisi pada panjang gelombang $720 \mathrm{~nm}$. Adanya tumpang tindih spektrum emisi dan absorbansi memungkinkan terjadinya transfer energi di dalam sistem yaitu interaksi emisi foton dengan molekul pewarna yang terjerap pada semikonduktor.

Sifat elektrokimia dari masing-masing ekstrak ditunjukkan pada pengukuran cyclic voltammogram seperti pada Gambar 3. Kedua ekstrak kulit jeruk memiliki tegangan oksidasi yang sama yaitu pada $+0,67 \mathrm{~V}$ relatif terhadap potensial $\mathrm{Ag} / \mathrm{AgCl}$. Ekstrak kulit jeruk nipis hanya menunjukkan satu langkah reduksi pada -1,02 V, sedangkan ekstrak kuit jeruk purut biasa menunjukkan dua langkah reduksi pada $-1,11$ dan $-1,74 \mathrm{~V}$. Berdasarkan hasil uji elektrokimia tersebut, diketahui bahwa ekstrak jeruk memiliki kecenderungan yang bersifat lebih oksidan sehingga tepat untuk dijadikan pewarna DSSC menggunakan semikonduktor tipe-n, salah satunya $\mathrm{ZnO}$.

Sebelum dilakukan analisis terhadap unjuk kerja DSSC, karakterisasi terhadap sifat fisika dari material $\mathrm{ZnO}$ disajikan pada Gambar 4. Berdasarkan formulasi Debye-Scherrer, besarnya kristalit $\mathrm{ZnO}$ dapat dihitung melalui persamaan:

$$
D=\frac{k \lambda}{\beta \cos \theta}
$$




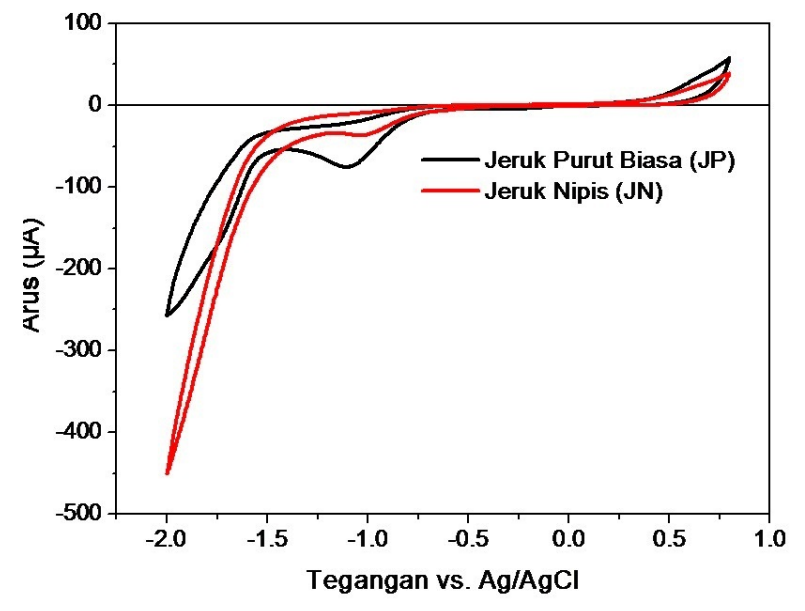

Gambar 3: Sifat elektrokimia ditunjukkan dengan cyclic voltammogram dari ekstrak jeruk biasa dan jeruk nipis.

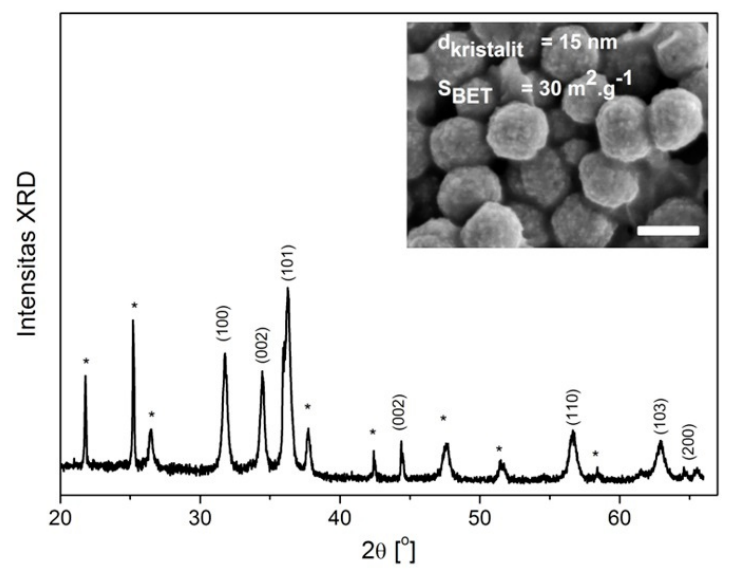

Gambar 4: Pola difraksi X-Ray ZnO pada kaca substrat FTO. Gambar yang disisipkan menunjukkan morfologi $\mathrm{ZnO}$ yang diperoleh dengan luas area spesifik serta ukuran kristalit $\mathrm{ZnO}$. Skala batang ekivalen dengan ukuran $100 \mathrm{~nm}$.

dengan D adalah ukuran kristalit (nm), k adalah faktor geometri $(0,9), \lambda$ adalah panjang gelombang $(\mathrm{nm}), \beta$ adalah lebar puncak pada nilai tengah intensitas (full-width at half maximum, FWHM), dan $\theta$ adalah sudut difraksi. Besarnya kristalit $\mathrm{ZnO}$ pada penelitian ini adalah $15 \mathrm{~nm}$. Namun demikian, berdasarkan karakterisasi SEM morfologi $\mathrm{ZnO}$ berupa bola spheris dengan ukuran rerata $200 \mathrm{~nm}$. Hal ini menunjukkan bahwa kristalit $\mathrm{ZnO}$ membentuk agregat berbentuk bola yang memiliki luas permukaan aktif sebesar $30 \mathrm{~m}^{2} / \mathrm{g}$. Berdasarkan karakterisasi struktur pori, $\mathrm{ZnO}$ dengan agregat bola memiliki karakter pori bimodal yang berasal dari pori inter-partikel(kristalit) atau intra-agregat dan pori interagregat $[4,16]$. Morfologi agregat bola ini sangat berguna untuk meningkatkan pemanenan cahaya karena faktor penghamburan cahaya internal (internal light scattering) sehingga efisiensi DSSC dapat ditingkatkan [3].

Performansi DSSC ditunjukkan pada kurva arus vs. tegan-
TABEL I: Parameter sel surya dari DSSC dengan iradiasi 100 $\mathrm{mW} . \mathrm{cm}^{-2}$. Nilai simpangan baku diambil dari hasil pengukuran empat sampel yang berbeda.

\begin{tabular}{lcccc}
\hline \hline Ekstrak & $\mathrm{V}_{o c}$ & $\mathrm{~J}_{s c}$ & $\mathrm{FF}$ & $\eta$ \\
& $($ volt $)$ & $\left(\mathrm{mA}_{\mathrm{c}} \mathrm{cm}^{-2}\right)$ & $(\%)$ & $(\%)$ \\
\hline
\end{tabular}

Jeruk Nipis $0,334 \pm 0,012 \quad 0,786 \pm 0,025 \quad 40,07 \quad 0,105$ Jeruk Purut $0,336 \pm 0,016 \quad 0,956 \pm 0,042 \quad 37,92 \quad 0,122$

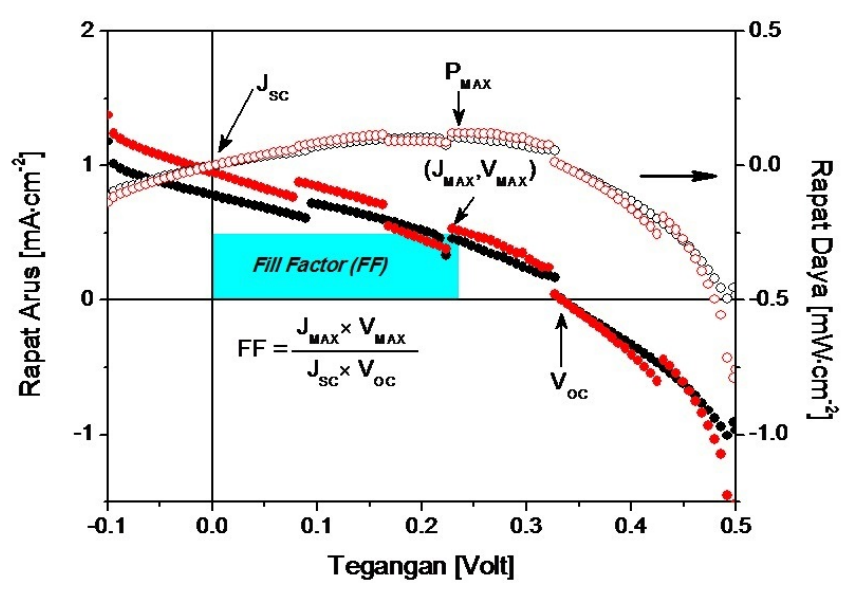

Gambar 5: Karakterisasi arus tegangan (bulat penuh) dan dayategangan (bulat kosong) untuk DSSC menggunakan ekstrak jeruk biasa (merah) dan jeruk nipis (hitam).

gan (J-V) dan daya vs tegangan (P-V) (Gambar 5). Karakteristik sel surya ditunjukkan dengan empat parameter yaitu: rapat arus hubungan singkat (short-circuit current density, $\mathrm{J}_{s c}$ ), tegangan hubungan terbuka (open-circuit voltage, $\mathrm{V}_{\circ c}$ ), faktor pengisian (fill factor, FF) dan efisiensi konversi energi $(\eta)$. Nilai FF dihitung dari rasio daya maksimum $\left(\mathrm{J}_{\max } \times \mathrm{V}_{\max }\right)$ terhadap daya teoretis $\left(\mathrm{J}_{s c} \times \mathrm{V}_{\mathrm{oc}}\right)$. Karakteristik sel surya hasil uji DSSC dengan masing-masing ekstrak kuit jeruk ditabulasikan pada Tabel I.

Pada Tabel I ditunjukkan bahwa nilai $\mathrm{V}_{\text {oc }}$ tidak bervariasi antara DSSC dengan ekstrak jeruk nipis ataupun jeruk purut yaitu berkisar pada nilai $0,335 \mathrm{~V}$. Hal ini menunjukkan bahwa beda potensial antara pita konduksi $\mathrm{ZnO}$ dan potensial reaksi redoks elektrolit tidak berbeda satu sama lain. Hal ini menunjukkan bahwa karakteristik elektronik $\mathrm{ZnO}$ dan elektrolit yang digunakan pada masing-masing DSSC adalah identik. Demikian pula dengan nilai FF yang tidak bervariasi secara signifikan sehingga dapat dijustifikasi bahwa karakteristik elektrik fabrikasi (series resistance $\mathrm{R}_{s}$ dan shunt resistance $\mathbf{R}_{s h}$ ) adalah identik. Nilai $\mathbf{R}_{s}$ dan $\mathbf{R}_{s h}$ ini dapat diestimasikasikan dari gradien kurva $\mathrm{J}-\mathrm{V}$ berturut-turut pada titik dekat $\mathrm{J}_{s c}$ dan $\mathrm{V}_{o c}$. Oleh karena itu, nilai arus foto yang dihasilkan dalam setiap DSSC dapat dikorelasikan secara spesifik dengan karakteristik optik dan elektrokimia dari variasi komposisi karotenoid dan flavonoid yang terkandung dalam ekstrak jeruk.

Ditinjau dari potensial/tegangan reduksi relatif terhadap 
tegangan referensi $\mathrm{Ag} / \mathrm{AgCl}$, ekstrak jeruk purut memiliki beda potensial -0.41 hingga $-1.14 \mathrm{~V}$ terhadap potensial pita konduksi $\mathrm{ZnO}$ pada kondisi vakum $(-0.7 \mathrm{~V}$ vs. $\mathrm{Ag} / \mathrm{AgCl})$ [22]. Hal ini berimplikasi bahwa energi bebas Gibbs $\left(-\Delta \mathrm{G}_{i n j}\right)$ untuk injeksi elektron pada kondisi tereksitasi pewarna ekstrak jeruk purut lebih besar dibandingkan pewarna ekstrak jeruk nipis, sehingga efisiensi injeksi elektron yang bersesuaian juga semakin besar. Selain itu, pada bahasan sifat optik ditunjukkan bahwa pada konsentrasi ekstrak yang sama, nilai absorptivitas esktrak jeruk purut lebih tinggi dibandingkan ekstrak jeruk nipis (sebagai contoh: $\mathrm{A}_{\lambda=475 \mathrm{~nm}}=$ 0,23 vs. 0,1) sehingga efisiensi pemanenan cahaya/foton juga lebih besar. Selain dua hal di atas, penggunaan ekstrak jeruk nipis cukup menarik untuk studi lebih lanjut. Hal ini dikarenakan adanya tumpang tindih spektrum absorpsi dan emisi ekstrak yang dapat menginduksi terjadinya transfer energi secara resonansi Förster antar molekul yang terjerab (teradsorbsi) secara berdekatan [23]. Adanya transfer energi ini akan meningkatkan kapasitas sensitisasi molekul pewarna oleh foton yang terhambur karena interaksi foton dengan semikonduktor serta interaksi dengan emisi foton dari molekul pewarna akibat penyerapan foton pada panjang gelombang yang bersesuaian. Secara umum, hasil preparasi DSSC dengan elektroda $\mathrm{ZnO}$ dan pewarna ekstrak jeruk menunjukkan efisiensi yang cukup baik untuk kelas pewarna alami dibandingkan dengan beberapa DSSC yang telah dilaporkan menggunakan ekstrak antosianin kulit manggis, bunga sepatu, bunga nanas kerang, dan lain-lain [5, 7, 16, 24, 25].

\section{SIMPULAN}

Dye-sensitized solar cells (DSSCs) dengan anoda $\mathrm{ZnO}$ tersensitisasi pewarna ekstrak jeruk telah difabrikasi dan dikarakterisasi. Pewarna ekstrak jeruk purut biasa kaya akan kandungan flavonoid seperti naringin, hesperidin dan tangeretin, sedangkan ekstrak jeruk nipis kaya akan kandungan quercetin, sakuranetin, dan tangeretin. Adapun kedua pewarna memiliki kandungan lutein (kelas karotenoid) yang identik. Kombinasi kandungan flavonoid dan karotenoid pada ekstrak jeruk mempengaruhi spektrum absorbsi dan emisi pada panjang gelombang tampak serta mempengaruhi potensial reduksi dari kedua ekstrak. Hasil uji arus-tegangan DSSC menggunakan elektroda aktif $\mathrm{ZnO}$ dan pewarna ekstrak jeruk menunjukkan nilai $\mathrm{V}_{o c}$ dan $\mathrm{FF}$ yang relatif sama, sehingga nilai $\mathbf{J}_{s c}$ yang berbeda dapat dikorelasikan dengan karakteritsik optik dan elektrokimia dari pewarna ekstrak jeruk. Rapat arus pada rangkaian singkat terbesar $\left(\mathrm{J}_{s c}=0,956 \mathrm{~mA} \cdot \mathrm{cm}^{-2}\right)$ dihasilkan DSSC dengan molekul pewarna ekstrak jeruk purut biasa dan efisiensi yang mampu dicapai sebesar $0,122 \%$. Hal ini dikarenakan energi bebas Gibbs untuk injeksi elektron dari kondisi tereksitasi ekstrak jeruk purut biasa lebih besar dibandingkan ekstrak jeruk nipis sehingga didapatkan injeksi elektron yang lebih efisien. Selain itu tingginya absorbansi molar ektrak jeruk purut biasa serta adanya tumpang tindih spektrum absorbsi dan emisi berimplikasi pada tingginya efisiensi pemanenan cahaya dalam piranti DSSC.
[1] M. Grätzel. J. Photochem. Photobiol. C, 4, 145-153 (2003).

[2] A. Kay, M. Grätzel, J. Solar Energy Materials \& Solar Cells, 44, 99-117 (1996).

[3] R.A. Wahyuono, Dye-Sensitized Solar Cells (DSSC) Fabrication with $\mathrm{TiO}_{2}$ and $\mathrm{ZnO}$ Nanoparticle for High Conversion Efficiency, Master Thesis, Institut Teknologi Sepuluh Nopember, 2013.

[4] R.A. Wahyuono, et al., Chemical Physics, 483, 112-121 (2017).

[5] R. Mahendra, R.A. Wahyuono, D. Sawitri, D.D. Risanti, DyeSensitized Solar Cells (DSSC) Based on ZnO non-and Verically Aligned Nanorods Structures, Proceeding of the $3^{\text {rd }}$ Applied Science for Technology Innovation, ASTECHNOVA, 3, 269-275 (2014).

[6] R.A. Wahyuono, et al., Open Chemistry, 14(1), 158-169 (2016).

[7] M. Iqbal, et al., Adv. Mater. Res., 1123, 219-222 (2015).

[8] R.A. Wahyuono, D.D. Risanti, Modeling and experiment of dye-sensitized solar cell with vertically aligned $\mathrm{ZnO}$ nanorods through chemical bath deposition, Proc. SPIE 9444, International Seminar on Photonics, Optics, and Its Applications (ISPhOA 2014), 94440Q (January 9, 2015); doi:10.1117/12.2081054.

[9] H. Chang, Y.-J. Lo, Journal of Solar Energy, 84, 1833-1847 (2010).

[10] E. Yamazaki, et al., Solar Energy, 81, 512-516 (2007).

[11] I. Eka Putri, et al., Advanced Materials Research, 1123, 325328 (2015).

[12] S. Agustini, et al., AIP Conference Proceedings, 1554(1), 66 (2013).
[13] R.A. Wahyuono, D.D. Risanti, Selection of Natural Dye Photosensitizer for Quasi-solid State Dye-sensitized Mesoporous $\mathrm{TiO}_{2}$ Solar Cell (DSC) Fabrication, Proceeding International Conference on Chemical and Material Engineering 2012, PSE.12, 1-6, 2012.

[14] Ernawita, et al., Eur. Food Res. Technol., 242, 1869-1881 (2016).

[15] Ernawita, et al., Antioxidants, 6(1), 11 (2017).

[16] A. Syukron, R.A. Wahyuono, D. Sawitri, D.D. Risanti. Adv. Mater.Res., 896, 183-186 (2014).

[17] R.A. Wahyuono, et al., AIP Conference Proceedings 1586(1), 78-81 (2014).

[18] M. Heneczkowski, M. Kopacz, D. Nowak, A. Kuzniar, Acta Pol. Pharm., 58, 415-420 (2001).

[19] A. Galvez, A. Iglesias, Comput. Aided Des., 43, 1683-1692 (2011).

[20] V. Domenici, et al., J. Agric. Food Chem., 62(38), 9317-9325 (2014).

[21] J.A. Sierra, et al., New J. Chem., 40, 1420-1429 (2016).

[22] K. Itaya, E. Tomita, Surface Science, 219, L515-L520 (1989).

[23] J.I. Basham, G.K. Mor, C.A. Grimes, ACS Nano, 4(3), 12531258 (2010).

[24] H. Zhou, L. Wu, Y. Gao, T. Ma, J. Photochem. Photobiol. A: Chemistry, 219, 188-194 (2011)

[25] S. Hao, J. Wu, Y. Huang, J. Lin, Journal of Solar Energy, 80, 209-214 (2006) 